\title{
Feeding preference and growth response of early adults abalone, Haliotis squamata on some macroalgae
}

\author{
DENY SUHERNAWAN YUSUP ${ }^{1, \boldsymbol{v}}$, I GEDE MAHARDIKA ${ }^{2}$, I WAYAN SUARNA ${ }^{3}$, \\ I NYOMAN ADIASMARA GIRI \\ ${ }^{1}$ Program of Biology, Faculty of Mathematics and Natural Sciences, Universitas Udayana. Jl. Raya Kampus Unud, Bukit Jimbaran, Kuta Selatan, Badung \\ 8036, Bali, Indonesia. Tel./fax.: +62-361-7019544, `email: dsyusup@unud.ac.id \\ ${ }^{2}$ Faculty of Animals Husbandry, Universitas Udayana. J1. Raya Kampus Unud, Bukit Jimbaran, Badung 8036, Bali, Indonesia \\ ${ }^{3}$ Faculty of Animals Husbandry, Universitas Udayana. Jl. Raya Kampus Unud, Bukit Jimbaran, Badung 8036, Bali, Indonesia \\ ${ }^{4}$ Institute for Mariculture Research and Fisheries Extention. Jl. Br. Gondol, Gerokgak, Buleleng 81101, Bali, Indonesia
}

Manuscript received: 21 June 2020. Revision accepted: 28 August 2020.

\begin{abstract}
Yusup DS, Mahardika IG, Suarna IW, Giri INA. 2020. Feeding preference and growth response of early adults abalone, Haliotis squamata on some macroalgae. Biodiversitas 21: 4369-4375. Study on early adult Haliotis squamata fresh feed has evaluated some macroalgae, however, a study on Enteromorpha sp., Halymenia sp., and Hypnea sp. have not been carried out. This study was proposed to evaluate the feeding preference (feed response and feed intake) and the growth performance of early adult $H$. squamata on some macroalgae. Seven species of macroalgae were evaluated as unpair feeding choice and the experiment design employed was completely randomized design. The results showed that $H$. squamata responded variously to the seven macroalgae species and the food deprivation (fasting) data showed mounting response to all macroalgae. Ulva lactuca and Enteromorpha sp. were the most responded which up to four times higher compared to the least responded i.e. Halymenia sp. and Sargassum sp. The highest to the lowest palatable feed intake (FI) were Gracillaria sp, Eucheuma spinosum, Ulva lactuca, Halymenia sp., Enteromorpha sp., Sargassum sp. and Hypnea sp. respectively. The first four palatable macroalgae resulted in various growth responses of $H$. squamata. Except for Halymenia sp., the feed intake (FI) rate showed an opposite linear correlation to growth response and FCR. The daily growth rate (g/day) was Ulva lactuca (0.104), Enteropmorpha sp. (0.085), Gracillaria sp. (0.084), and Halymenia sp. (0.016).
\end{abstract}

Keywords: Abalone, feeding, Haliotis squamata, macroalgae, preference

\section{INTRODUCTION}

Slow growing marine herbivores, abalone is one of high-value marine fisheries products at the international fisheries market. Current market supply is coming from some leading abalone producer countries such as China, South Korea, South Africa, and Australia and the vast majority being produced by 2016 in China $(139,697 \mathrm{mt})$ and South Korea (16,042 mt) (Coock 2019). Nonetheless, the role of Indonesia in fulfilling international abalone demand is still negligible. The abalone industry in Indonesia has relatively just developed compared to other aquaculture industries such as shrimp, seaweed, and milkfish (Setyono 2006). Two of seven abalone species found in Indonesia waters (Setyono 2006), Haliotis squamata, and $H$. asinina have been progressively developed for mariculture in Indonesia. As the finding of disease on $H$. asinina, current most research concern is on $H$. squamata particularly on feeding development (Prihadi et al. 2018).

$H$. squamata has been widely exploited since a long time ago in its natural habitat by local people in several regions, e.g. Bali (Cemagi and Pekutatan waters), East Java (Banyuwangi), and West Java (Pangandaran and Pameumpeuk) (Yusup et al. 2014). A similar problem counted by abalone catcher at those regions is declining of yield and abalone size, this indicates that the natural resource of abalone at those regions seems overexploited. Therefore, the development of abalone mariculture in Indonesia is strategic to counter abalone source exploitation as done by other countries to save the natural abalone source population (Coock 2019). Such abalone mariculture development in Indonesia, however, has a crucial obstacle i.e. feed availability. Commercial feed (pellet) has not available yet in Indonesia market unless it is imported, leading to unparalleled capital gain.

Research on feed development for $H$. squamata has been carried out by several studies in Indonesia, fresh Ulva sp. and Gracillaria sp. were combined with other macroalgae species, such as Eucheuma cottonii (Susanto et al., 2010), Eucheuma spinosum (Prihadi et al. 2018), and Sargassum sp. evaluated as artificial compound diet (Giri et al., 2016). These studies similarly showed a positive growth response of $H$. squamata. However, no study has been done to evaluate successfully farmed macroalgae, Halymenia sp., or macroalgae that are sufficiently available in the nature such as Enteromorpha sp. and Hypnea sp. for early adult $H$. squamata.

Optimal foraging theory implies that the most nutritious food for animals is the most preferred food. However, previous studies reported that nutrient content is not the main determinant in choice feeding of Haliotis sp., it is also affected by other factors such as thallus texture of macroalgae (Roussel et al. 2020), previous feeding 
experience (Zhanhui et al. 2010), and antinutrients (Bansemer et al. 2014). Therefore, feeding response behavior must be considered on further study of Haliotis sp. feeding development (Roussel et al. 2020). Knowledge of abalone feeding response to a given seaweed species is the basis for sustainable diet development due to the expected correlation between preferred feed and growth performance. This study was proposed to evaluate feeding preference and growth response of $H$. squamata to some macroalgae plenty available.

\section{MATERIALS AND METHODS}

\section{Procedures}

\section{Choice feeding}

The choice feeding of Haliotis squamata to some macroalgae was evaluated by employing unpair feeding test (no choice feeding). Seven species of macroalgae were tested i.e. Ulva lactuca, Gracillaria sp., Eucheuma spinosum, Halymenia sp., Sargassum sp., Hypnea sp. and Enteromopha sp. These macroalgae were collected from different waters i.e. Sargassum sp., E. spinosum, and $U$. lactuca were collected from Serangan Island, Denpasar, Bali, Indonesia while Enteromorpha sp., Hypnea sp., Gracillaria sp. and Halymenia sp. were collected from Gondol waters, Buleleng, Bali, Indonesia.

The H.squamata tested were resulted from breeding (F3) at Institute for Mariculture Research and Fisheries Extention, Gondol, Buleleng, Bali. The abalone was clustered into two classes as juvenile and early adult ones. The average body weight and shell length of juvenile were $2.57 \pm 0.40 \mathrm{~g}$ and $24.46 \pm 1.30 \mathrm{~mm}$, respectively. While the average body weight and shell length of early adults were $6.94 \pm 0.61 \mathrm{~g}$ and $34.95 \pm 1.2 \mathrm{~mm}$, respectively.

The test was carried out in plastic containers $(40 \times 30 \mathrm{x}$ $20 \mathrm{~cm})$ put in outdoor tanks $(80 \times 150 \times 100 \mathrm{~cm})$ filled with continuous-filtered seawater (90\% of tank volume) and aerated to supply dissolved oxygen. Each alga species was replicated twice (total 14 containers; @) 20 individuals). Another seven containers were without animal -as the control - to observe the effect of soaking onto the weight of algae.

The experiment design employed was completely randomized design (CRD). The test was carried out for 10 days and the algae tested was replaced every day to ensure its freshness. The variable observed were feeding response and feed intake. The variables were monitored twice a day i.e. in the morning (07 am) and evening (07 pm).

The feeding response depicts the response of $H$. squamata on to the feed when it has just provided, and was described as the number of individuals indicating feeding activity (i.e. chewing feed tested). The response was observed three times (i.e. 20, 60, and 120 minutes after feed given) at each monitoring period.

The feed intake (feed consumption) depicts feed palatability and was described as the number of feeds consumed over period feeding activities monitoring (every 12 hours). The feed intake was calculated by formula beneath (at growth response section).

\section{Feed deprivation (fasting)}

The experiment was aimed to observe the effect of feed deprivation on feeding response. The algae species tested were the same as the species used for choice feeding experiments (i. e seven species of algae). The experiment was run in 14 plastic containers of $40 \times 30 \times 20 \mathrm{~cm}$ (each contains 10 individuals). The containers were put in tanks previously used for choice feeding experiments. The individual body weight was measured at the initial $(2.87 \pm 0.75 \mathrm{~g}$.) and the final of the experiment.

The abalone was fasted for 24, 48, 72, and 96 hours continuously. The experiment design was completely randomized design (CRD) with two replications for each alga tested. The variable observed was feeding response, described as the number of individuals indicating feeding activity (i.e. chewing feed tested). The response was observed once for every fasting period i.e. in the evening (started by $6.00 \mathrm{pm}$ ). The feeding response was evaluated three times (i.e. 60, 120, and 180 minutes after feed given) for every fasting period, and thereafter the feed tested were recollected and replaced with the new one to ensure its freshness.

\section{Growth response}

Further experiment was growth response attributed to the digestibility of macroalgae consumed. The algae evaluated were most responded algae (at choice feeding experiments) and such selection also considered the availability and the novelty of the algae. Four of the seven macroalgae were chosen, i.e. Ulva lactuca, Gracillaria sp., and Enteromorpha sp. which are plenty in nature either at Denpasar or Gerokgak, Buleleng, Bali, and Halymenia sp. which has widely been farmed. The feed was evaluated as a single feed (unpair feeding test). The experiment was carried out in floating net cages $(40 \times 33 \times 40 \mathrm{~cm})$ with 2 $\mathrm{mm}$ in mesh size- the optimum mesh size for fresh feeding experiments (Yusup, 2016).

The experiment design was completely randomized design with three replications (total of 12 experiments units). Each unit consists of 21 early adult individuals (body weight: $6.55 \pm 3.17 \mathrm{~g}$, shell length: $35.17 \pm 5.74 \mathrm{~mm}$; width shell: $22.12 \pm 3.66 \mathrm{~mm}$ ). One experimental unit for each algae species was tested without animal for evaluating soaking effect -as the control. The net was put in outdoor tanks $(150 \times 75 \times 1000 \mathrm{~cm})$ filled with continuous-filtered seawater circulation ( $90 \%$ of the tank volume) and aerated and the tank was siphoned every day in the morning $(08.00$ am).

The experiment was run for eight weeks. Feeds were replaced every 48 hours to prevent feed degradation due to soaking, and the remaining feed (uneaten feed) and the control were recollected and weight. The new feed replacement was carried out in the afternoon $(04.00 \mathrm{pm})$.

Water quality i.e. water temperature was daily observed by means of a thermometer, and $\mathrm{pH}, \mathrm{NO}_{2}$, and $\mathrm{NO}_{3}$ and ammonium were observed every three days by means of tools kit (brand "Sera").

The variable observe were feed intake (feed consumption), growth response, and food conversion ratio 
(FCR), calculated by adopting the formula of O'Mahoney et al. (2014).

Feed intake (feed consumption $) / \mathrm{FI}=(\mathrm{Wo} * \mathrm{CF})-\mathrm{Wt}$

Correction factor $(\mathrm{CF})=\mathrm{Wtc} / \mathrm{Woc}$

Daily feed intake rate $=(\mathrm{FI} / \mathrm{t}) / \mathrm{Wa}$

Absolute growth (body weight) $=\mathrm{BWt}-\mathrm{Bwo}$

Absolute growth (shell length) $=\mathrm{SLt}-\mathrm{SLO}$

Absolute growth (shell wide) $=\mathrm{SWt}-\mathrm{SWo}$

Feed conversion ratio $(\mathrm{FCR})=$ Total feed intake $/(\mathrm{BWt}-\mathrm{Bwo})$

Where:

Wa: abalone weight $(\mathrm{g})$; Woc: initial weight of feed (without animal/control) (g); Wtc: final weight of feed (without animal/control) (g); Wo: initial feed weight (g); Wt: Remaining feed (uneaten feed) weight $(\mathrm{g})$; LS: Length of shell (mm); WS: Width of shell

\section{Data analysis}

The effect of various treatments on choice feeding response was analyzed by employing two-ways ANOVA with algae as the first factor and time and size as the second factor, and the growth response was analyzed by employing one-way ANOVA. When the response was significantly different, the post hoc test was used to observe the significance of treatments at $\mathrm{P}<0.05$ for all tests.

\section{RESULTS AND DISCUSSIONS}

\section{Choice feeding}

The results showed a significant feeding response of $H$. squamata to macroalgae species (P: 0.000, Table 1). The results showed the hierarchy response of $H$. squamata to macroalgae, U. lactuca, and Enteromorpha sp. were responded at the highest, while Halymenia sp. and Sargassum sp. were least responded. Neither algae species was certainly responded by juvenile nor early adult individuals (P: 0.300), though feeding response of juvenile and early adult individuals was significantly different (P:0.000; Table 1, Figure 1.A). This finding indicates that $H$. squamata has a wide range of feed types and it does not show size-specific feed preference. This finding is consistent with previous studies, Haliotis sp. responded differently to various alga species tested either as fresh or in a formulated feed (Viera et al. 2011; Angel et al. 2012; O’Mahoney et al. 2014).

This study showed non-significantly different between day and night feeding activities (diel activity) (P: 0.435, Table 1, Figure 1.B). This finding indicates that - as other abalone species- $H$. squamata actives to forage either at day or night, though it seems to be more active at night. Haliotis sp. is real nocturnal animal though abalone also feeds actively at daylight (Buss et al. 2015; Roussel et al. 2020). In terms of farming management point of view, such $H$. squamata feeding response behavior is important for controlling feeding time and feed proportion, the feed proportion given in the evening is supposed to be more than in the morning period.

Table 1. The number of individuals of Haliotis squamata responding fresh macroalgae

\begin{tabular}{|c|c|c|c|c|}
\hline Feed & $\begin{array}{l}\text { Feed } \\
\text { response }\end{array}$ & $\begin{array}{c}\text { Diel } \\
\text { activity }\end{array}$ & \multicolumn{2}{|c|}{$\begin{array}{c}\text { Size } \\
\text { (shell length) }\end{array}$} \\
\hline U. lactuca & $7.731^{\mathrm{a}}$ & Night $4.746^{a}$ & Early adult & $5.657^{\mathrm{a}}$ \\
\hline Enteromorpha sp. & $7.196^{\mathrm{a}}$ & Day $4.495^{a}$ & Juvenile & $3.773^{b}$ \\
\hline Gracillaria sp. & $5.401^{\mathrm{b}}$ & & & \\
\hline E.spinosum & $4.588^{\mathrm{bc}}$ & & & \\
\hline Нурпеа sp. & $3.993^{c}$ & & & \\
\hline Halymenia sp. & $1.995 \mathrm{~d}$ & & & \\
\hline Sargassum sp. & $1.438 \mathrm{~d}$ & & & \\
\hline
\end{tabular}

Note: The superscript notation at the same column shows a significance at $5 \%$

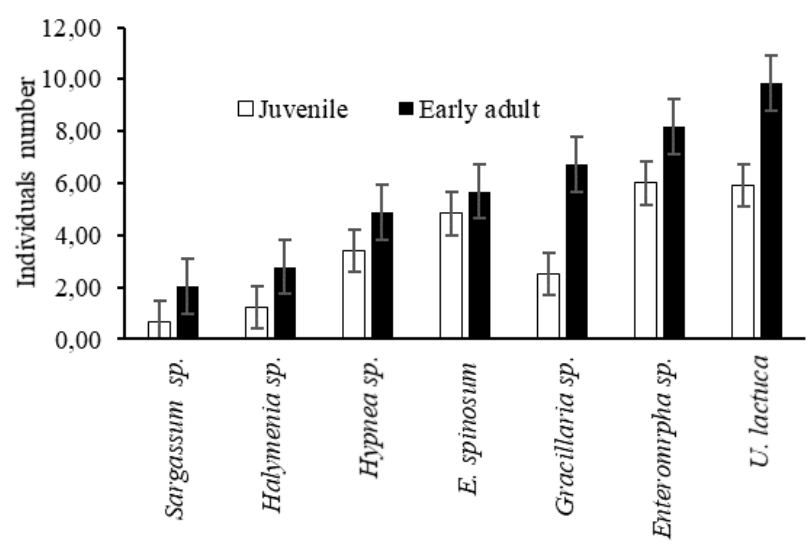

$\mathbf{A}$

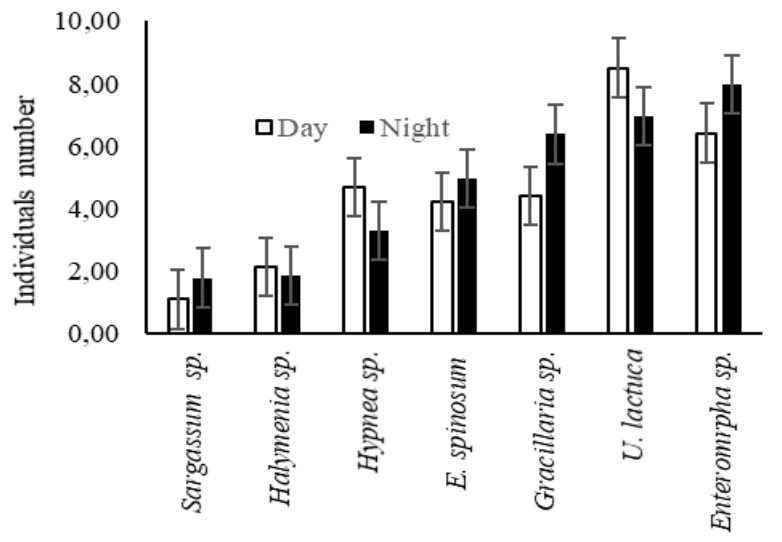

B

Figure 1. The feeding response of Haliotis squamata. A. Between juvenile and early adult individuals, B. At day and night 


\section{Feed deprivation (fasting)}

This study showed that the duration of fasting to some extent alters the feeding response of $H$. squamata, and the response varies among algae tested (Table 2). The result showed that the longer feed deprivation duration increases the feeding response of $H$. squamata, the feeding response increases sharply by 96 hours (4 days) fasting (Figure 2). This finding is relevant to previous studies, foraging activity of $H$. laevigata increased after fasted, even during daylight (Buss et al. 2015), and Nile tilapia fish showed hyperphagia after lowering food supply (Ali et al. 2016). Such increase foraging and feeding activities seem to compensate feed gain.

After 96 hours of fasting, all individuals showed a loss of body weight (Table 2). The individuals fed Enteromorpha sp. and U. lactuca showed least bodyweight loss, individuals fed Gracillaria sp., Hypnea sp. and Sargassum sp. showed moderate body weight loss and individual fed E. spinosum and Halymenia sp. showed considerably body weight. This study provides evidence that starvation has a significant impact on body weight loss (Figure 2), which means that $H$ squamata experience auto biodegradation by degrading stored energy to fulfill daily energy needs. A similar finding was reported by Ziheng et al. (2017) on juvenile tongue sole (Cynoglossus semilaevis) and Vidal et al. (2018) on a neotropical fish species (Jeninsia multi dentata) that the species loss of body weight when starvation level increase, and likely that the fish use stored food from some organ (Vidal et al. 2018).

\section{Feed intake}

The feed intake (feed consumption) rate of $H$. squamata, indicating feed palatability, showed significant differences among macroalgae evaluated (P:0,0163, Table 3). Overall, the results showed that five algae species mostly consumed were Gracillaria sp., E. spinosum, $U$. lactuca, Halymenia sp., and Enteromorpha sp., while two algae species were less consumed i.e. Sargassum sp. and Hypnea sp. The consumption rate of Gracillaria sp. was almost 3.5 times higher compared to the least consumed i.e. Hypnea sp. The feed consumption increased with abalone size (P: 0.0006, Table 3, Figure 3.A). Nevertheless, statistical analysis showed no correlation between macroalgae species and body size of abalone (P:0.184).

Once food is detected by the tentacles, abalone will protrude buccal and esophagus and subsequently engulf the food. Food is mechanically ingested in buccal cavity using radula, a ribbon-like membrane contains numerous chitinous teeth (Zhanhui et al. 2010). Bansemer et al. (2014) take a note that Haliotis sp. consumed various seaweed and showed preference to seaweed species, it indicates that macroalgae have different palatability. Such various seaweed palatability could be related to the macroalgae characters, such as feeding attractant or feeding stimulant (Angel et al. 2012), nutrient content (Bansemer et al. 2016), thallus texture (Roussel et al. 2020).
The high palatability of Gracillaria sp. is consistent with a previous study on $H$. iris (Zhanhui et al. 2010) which shows high preference for Gracillaria sp. The high consumption of other macroalgae has also been reported by other studies such as E. spinosum (Prihadi et al. 2018), $U$. lactuca (Angel et al. 2012; Bansemer et al. 2016) and Enteromorpha sp. (Roussel et al. 2020).

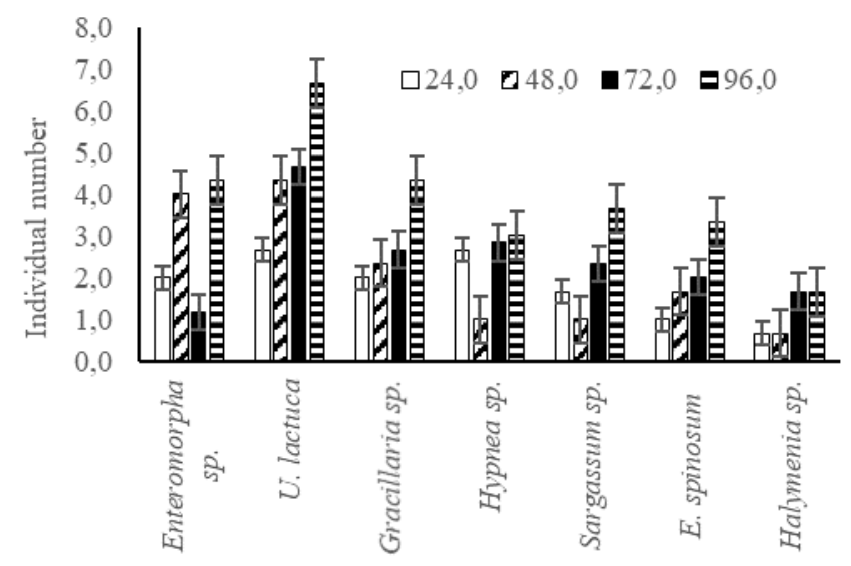

Figure 2. The feeding response of Haliotis squamata fasted for $24,48,72$, and 96 hours

Table 2. The average feeding response of fasted H. squamata and the bodyweight loss

\begin{tabular}{lcccc}
\hline \multicolumn{1}{c}{ Feed } & $\begin{array}{c}\text { Feeding } \\
\text { response } \\
\text { (individuals) }\end{array}$ & $\begin{array}{c}\text { Initial } \\
\text { weight } \\
(\mathbf{g})\end{array}$ & $\begin{array}{c}\text { Final } \\
\text { weight } \\
(\mathbf{g})\end{array}$ & $\begin{array}{c}\text { Bodyweig } \\
\text { ht loss } \\
(\boldsymbol{\%})\end{array}$ \\
\hline Halymenia sp. & 1.2 & 3.247 & 3.103 & 4.4 \\
E. spinosum & 2.0 & 2.571 & 2.466 & 4.1 \\
Sargassum sp. & 2.2 & 3.080 & 2.979 & 3.3 \\
Hypnea sp. & 2.4 & 3.050 & 2.971 & 2.6 \\
Gracillaria sp. & 2.8 & 2.613 & 2.547 & 2.5 \\
Enteromorpha sp. & 2.9 & 3.050 & 3.015 & 1.1 \\
U. lactuca & 4.6 & 2.275 & 2.228 & 2.1 \\
\hline
\end{tabular}

Table 3. Daily individual fed intake (g ind-1 day-1) of Haliotis squamata on fresh macroalgae

\begin{tabular}{|c|c|c|c|c|c|}
\hline Feed & $\begin{array}{c}\text { Feed } \\
\text { consumption }\end{array}$ & & $\begin{array}{l}\text { iel } \\
\text { vity }\end{array}$ & $\begin{array}{r}\text { Size } \\
\text { (shell le }\end{array}$ & ngth) \\
\hline Gracillaria sp. & $0.55^{\mathrm{a}}$ & Night & $0.39^{\mathrm{a}}$ & Early adult & $0.44^{\mathrm{a}}$ \\
\hline E. spinosum & $0.41^{\mathrm{ab}}$ & Day & $0.25^{\mathrm{a}}$ & Juvenile & $0.20^{\mathrm{b}}$ \\
\hline U. lactuca & $0.36^{\mathrm{abc}}$ & & & & \\
\hline Halymenia sp. & $0.33^{a b c}$ & & & & \\
\hline Enteromorpha sp. & $0.27^{b c}$ & & & & \\
\hline Sargassum sp. & $0.16^{\mathrm{c}}$ & & & & \\
\hline Hypnea sp. & $0.15^{\mathrm{c}}$ & & & & \\
\hline
\end{tabular}

Note: The superscript notation at the same column shows a significance at $5 \%$ 


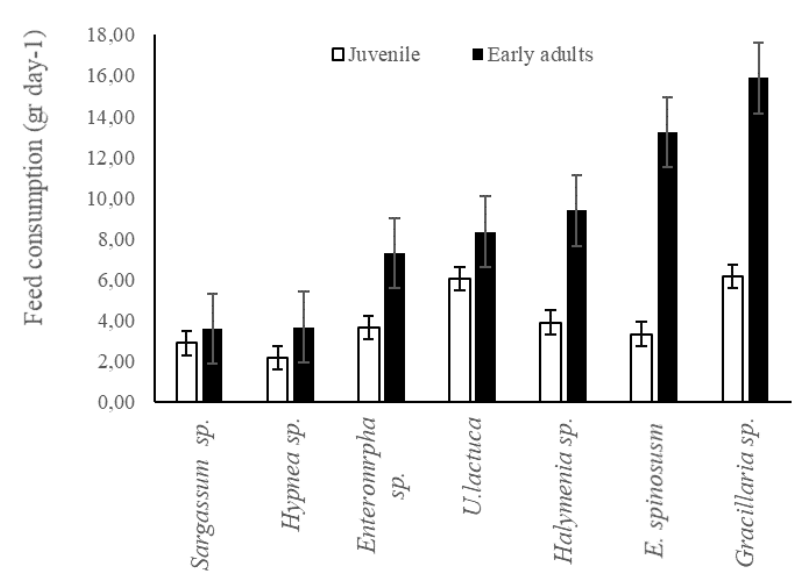

$\mathbf{A}$

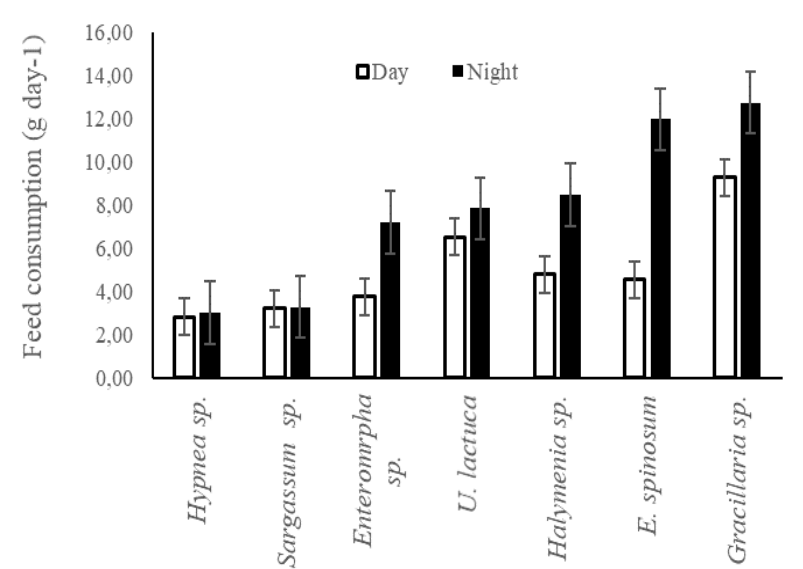

$\mathbf{B}$

Figure 3. The average of total feed consumption (feed intake) $\left(\mathrm{g} \mathrm{day}^{-1}\right)$ of Haliotis squamata: A. Juvenile and early adult, B. At day and night. Note: the population of each feed is 20 individuals

The least consumed seaweeds were Sargassum sp. and Hypnea sp. Likely, the radula of $H$ squamata is not effective to ingest effectively Sargassum sp. which has tough texture. It is evidenced by remaining (uneaten) Sargassum sp. recollected indicates grasping of $H$. squamata. Less consumption rate also is shown by Hypnea sp. (Table 2) and to the best our knowledge, this finding is the first study of palatability of Hypnea sp. by $H$. squamata. Nevertheless, this finding is not consistent with Angel et al. (2012) that reported a high preference of $H$. asinina to Hypnea pannosa. Such different responses could parsimoniously be related to abalone species difference, various abalone species consume various seaweed (Bansemer et al. 2014).

Regarding the results of feed palatability, it is likely that $H$ squamata also prefer filamentous and thinner algae such as $U$. lactuca, E. Spinosum, Halymenia sp., and Enteromorpha $\mathrm{sp}$. This finding is relevant to those reported by Roussel et al. (2020) on feed preference of green ormer abalone ( $H$. tuberculata). The finding of this study also supports Ansary et al. (2018) that Sargassum sp. is more palatable and digestible when it is fed as a powder meal (formulated feed) rather than as fresh feed. The novel finding of this study was that Halymenia sp. consumption rate was non significantly different from $U$. lactuca known as one of the most preferred seaweed for abalone (Bansemer et al. 2016). This might be related to the soft texture and nutrition value (i.e. protein content) of Halymenia sp., which is almost similar to the protein content of Gracillaria sp. and U. lactuca (Yusup, 2020). This implies that Halymenia sp. should be involved in further $H$. squamata feed development.

The feed intake rate was not significantly different between day and night (P: 0.109, Table 3). Nevertheless, $H$. squamata was more active for feeding at night than a day
(Figure 3.B). This provides another evidence that abalone is naturally nocturnal animal as reported by many abalone studies.

\section{Growth}

Abalone is known as herbivorous mollusks, and macroalgae containing high carbohydrates is the main feed source for juvenile and adult abalone (Bansemer et al. 2014). Food engulfed by abalone will be stored at crop before further digested enzymatically along its alimentary canal which will be continued by absorption and cellular process to produce energy. The energy retention resulted from cellular processes will be used for activities and growth. Therefore, understanding feeding response is necessary to develop the most suitable feed expected to result in maximum growth response for economically beneficial of abalone production (Baek et al. 2019).

Regarding the results of the feeding response and feed intake experiment results above, four potential algae i.e. Gracillaria sp., Enteromorpha sp., $U$. lactuca, and Halymenia sp. were selected for further observation on the growth response of $H$. squamata. Though $E$. spinosum palatability was remarkably high, it was excluded because this species has excellent market value as the source of carrageen widely used for food and medical industry (Pedra et al. 2017). Such consideration on macroalgae selection also involves the availability and economical value of seaweed reason as suggested by Venter et al. (2016). Gracillaria sp., U. lactuca, and Enteropmorpha sp. are plenty in the nature surrounding Bali waters and Halymenia sp. has been successfully farmed by local fishermen. The economic value of these seaweeds, however, has not been developed yet. Therefore, this study is also expected to extend the market value of these algae. 
Table 4. Feed consumption (FI) and growth response of Haliotis squamata

\begin{tabular}{lcccccc}
\hline \multicolumn{1}{c}{ Algae } & $\begin{array}{c}\text { DFC } \\
(\mathbf{g} \text { feed/g abalone/day) }\end{array}$ & $\begin{array}{c}\text { Feed consumption } \\
(\mathbf{g} / \mathbf{i n d} / \mathbf{d a y})\end{array}$ & $\begin{array}{c}\text { FCR } \\
(\mathbf{\%})\end{array}$ & $\begin{array}{c}\text { Final body } \\
\text { weight }(\mathbf{g})\end{array}$ & $\begin{array}{c}\text { Final shell } \\
\text { length }(\mathbf{m m})\end{array}$ & $\begin{array}{c}\text { Final shell width } \\
(\mathbf{m m})\end{array}$ \\
\hline Gracillaria sp. & $0.163 \pm 0.01^{\mathrm{a}}$ & $1.21 \pm 0.03^{\mathrm{a}}$ & 13.7 & $5.02 \pm 0.85^{\mathrm{b}}$ & $9.56 \pm 1.14^{\mathrm{a}}$ & $6.21 \pm 0.40^{\mathrm{b}}$ \\
Enteromorpha sp. & $0.126 \pm 0.02^{\mathrm{b}}$ & $0.93 \pm 0.07^{\mathrm{b}}$ & 10.3 & $5.10 \pm 0.29^{\mathrm{ab}}$ & $9.81 \pm 0.75^{\mathrm{a}}$ & $6.81 \pm 0.44^{\mathrm{b}}$ \\
U. lactuca $_{\text {Halymenia } \text { sp. }}$ & $0.109 \pm 0.01^{\mathrm{bc}}$ & $0.89 \pm 0.05^{\mathrm{b}}$ & 8.1 & $6.25 \pm 0.85^{\mathrm{a}}$ & $11.08 \pm 0.98^{\mathrm{a}}$ & $7.96 \pm 0.33^{\mathrm{a}}$ \\
\hline
\end{tabular}

The result of the growth response experiment showed that $H$. squamata responded variously to the macroalgae and the growth response showed a significant difference among diet in all growth parameters (Table 4). The highest growth parameters response was shown by individuals fed $U$. lactuca, while the lowest growth response was shown by individuals fed Halymenia sp. This finding is consistent with the previous study reported the excellence of $U$. lactuca and Enteromorpha intestinalis for $H$. tuberculate growth (Roussel et al. 2020) and Gracillaria sp. for H. discus hannai ino (Zhanhui et al. 2010). Compare to other studies on $H$. squamata, the growth response of individual fed Gracillaria sp. and Ulva sp. found in this study are higher than that reported by Prihadi et al. (2018) i.e. Gracillaria sp. (BW: $0.045 \mathrm{~g} \mathrm{day}^{-1}$ and LS: $0.063 \mathrm{~mm}$ day $^{-1}$ ) and Ulva sp. (BW: $0.084 \mathrm{~g} \mathrm{day}^{-1}$ and LS: $0.159 \mathrm{~mm}$ day $\left.^{-1}\right)$. Such difference is likely related to various nutrient content within the algae species as reported by (Bansemer et al. 2014) and might also be related to energy expenditure because of different experiment places. This experiment was run at in-door tanks, while the other two $H$. squamata studies were carried in nature which might have higher water shaking leading to more energy expenditure by abalone.

The result of food conversion ratio (FCR) varies among those algae evaluated (Table 1). The lowest FCR was shown by the feed of Ulva lactuca and the highest FCR was shown by feed of Halymenia sp. The FCR hierarchy of the remaining algae showed opposite parallel to that of feed intake.

The feed intake (feed consumption) and daily feed consumption (DFC) of $H$. squamata are presented in Table 4. The result showed a significant difference among macroalgae $(\mathrm{P}<0.05)$. Gracillaria sp. was mostly consumed, such as high feed intake, however, was not linear to the growth response. The lowest feed intake was shown by the feed of Halymenia sp., though this alga was well responded. Such low feed intake of Halymenia sp. is linear to the low growth response. This raises a hypothesis that the feeding response of $H$. squamata to Halymenia sp. might be related to the soft texture and phagostimulant of Halymenia sp., nevertheless Halymenia sp. is likely also contain secondary metabolite which could act as an antinutritive for $H$. squamata digestion. The study of Sanger et al. (2019) showed that phenolic content of Halymenia durvilae was higher than Gracillaria salicornia, and the study of Sarojini et al. (2016) showed phenolic content of Gracillaria corticata is higher than in Ulva fasciata and Enteromorpha compressa. Some plants and macroalgae contain anti-nutritive polyphenol which could reduce digestive enzyme activity (Chater et al. 2015). Mostly Phenolic often found in macroalgae (Mekinic et al. 2019) was recognized as a potential antinutritive.

Considering food conversion ratio (FCR), the most efficient feed was shown $U$. lactuca compare to Enteromoprpha sp. and Gracillaria sp. Taken account with growth response and high FCR indicate that $U$. lactuca is the most potential feed material for $H$. squamata feed development. This finding provides another evidence that Ulva sp. is one of the main foods for Haliotis sp. (Bansemer et al. 2014).

Physical and chemical water quality was water temperature $\left(29-31^{\circ} \mathrm{C}\right)$, water $\mathrm{pH}(7.5-8.5)$, while $\mathrm{NO}_{2}$, $\mathrm{NO}_{3}$, and ammonium were undetected. The range of water quality parameters was at abalone tolerance, thus the growth response of $H$. squamata to some extent was not affected by water quality.

Taken all those above, it can be concluded that $H$ squamata has a wide range of feed types and showed high preference for Gracillaria sp. The feeding response to some extent is affected by satiation level. This study showed that U. lactuca is the main food for H. squamata, and provides novel evidence that Enteromoprpha sp is another potential macroalgae. Further study is crucial by evaluating these macroalgae as combination feeds formula for further $H$. squamata feed development.

\section{ACKNOWLEDGEMENTS}

We are grateful to Prof. I Wayan Kasa for reading the manuscript. We thank Institute for Mariculture Research and Fisheries Extension, Marine and Fisheries Ministry, Gondol, Gerokgak, Buleleng, Bali, Indonesia for providing animal and experimental facilities. We also thank Dessy Damayatni, Sumarto, and Arsyad for their assistance in taking care of abalone, collecting seaweed, and collecting data.

\section{REFERENCES}

Ali TES, Martines-Llorens S, Monino AV, Cerda MJ, Tomas-Vidal A. 2016. Effect of weekly feeding frequency and previous ration restriction on the compensatory growth and body composition of Nile tilapia fingerlings. Egypt $\mathrm{J}$ Aquat Res 42: 357-363. DOI: 10.1016/j.ejar.2016.06.004.

Angel AR, Pirozzi I, de Nys R, Paul NA. 2012. Feeding preference and the nutrition value of tropical algae for the abalone Haliotis asinina. PLoS ONE 7 (6): e38857. DOI: 10.1371/journal.pone.0038857.

Ansary MWR, Jeong HS, Lee KW, Kim HS, Kim J, Yun A, Cho SH, Kim PY, Kim TI. 2018. The effect of substituting Undaria pinnatifida in 
formulated fed with Sargassum horneri on growth and body composition of juvenile abalone (Haliotis discus, Reeve 1846). J App Phycol 30. DOI:10.1007/s10811-018-1672-2.

Baek SI, Kim PY, Ansary MWR, Lee KW, Cho SH, Kim HS, Byun SG 2019. The effect of dietary substitution of Undaria pinnatifida with carrot leaf by-product on the growth and body composition of juvenile abalone (Haliotis discus, Reeve 1846). J App Phycol 31 (5): 3235-3243. DOI:10.1007/s10811-019-01796-8.

Bansemer MS, Qin JG, Harris JO, Duong DN, Hoang TH, Howarth GS, Stone DAJ. 2016. Growth and fee utilization of green lip abalone (Haliotis laevigata) fed nutrient-enriched macroalgae. Aquac 452: 62 68. DOI: 10.1016/j.aquaculture.2015.10.025.

Bansemer MS, Qin JG, Harris JO, Howarth GS, Stone DAJ. 2014. Nutritional requirement and use of macroalgae as ingredients in abalone feed. Rev Aquac 5: 1-15. DOI: 10.1111/raq.12085.

Buss JJ, Jones DA, Lumsden A Harris JO, Bansemer MS, Stone DAJ. 2015. Restriction feed ration has more effect than diet type on the feeding behavior of green lip abalone, Haliotis laevigata. Mar Fresh Water Behav Phys 48 (1): 51-70. DOI 10.1080/10236244.2014.990701.

Chater PI, Wilcox MD, Houghton D, Pearson JP. 2015. The role of seaweed bioactive in the control of digestion: Implication for obesity treatments. Royal Soc Chem Food Funct 6 (11): 3420-3427. DOI: 10.1039/c5fo00293a.

Coock PA. 2019. Worldwide abalone production statistics. J Shellfish Res 38 (2): 401-404. DOI: 10.2983/035.038.0222.

Giri N.A., Marzuqi M, Rusdi I, Andriyanto W. 2016. Formulation of compounded feed by using seaweed as raw material for growth-out of abalone Haliotis squamata. Jur Ris Akuakultur 11 (1): 75-83. DOI: http://dx.doi.org/10.15578/jra.11.1.2016.75-83

Mekinic IG, Skroza D, Simat V, Hamed I, Cagalj M, Perkovic ZP. 2019 Phenolic content of brown algae (Phaeophyceae) species: Extraction, identification, and quantification. Biomol 9 (6): 244. DOI: 10.3390/biom9060244.

O’Mahoney M, Rice O, Mouzakitis O, Burnel G. 2014. Toward sustainable feed for abalone culture: Evaluating the use of mixed species seaweed meal in formulated feed for the Japanese abalone, Haliotis discus hannai. Aquac 400: 9-16. DOI: 10.1016/j.aquaculture.2014.02.036

Pedra LM, Ramlov F, Maraschin M, Hayashi L. 2017. Cultivation of the red seaweed Kappaphycus alvarezii with effluent from shrimp cultivation and brown seaweed extract: Effect on growth and secondary metabolism. Aquac 479: 297-303. DOI 10.1016/j.aquaculture.2017.06.005

Prihadi TH, Rasidi I, Ardi I, Widiyati A, Wiyanto DB. 2018. Potency of different seaweeds as diets for developing abalone (H. squamata) culture in Nusa Penida Island, Bali. E3S Web of Conference 47: 02004. DOI: 10.1051/e3sconf/20184702004.p:8.

Roussel S, Poitevin P, Day R, Le Grand F, Striger-Pouvreau V, Leblanc C, Huchette S. 2020. Haliotis tuberculata, a generalist marine herbivore that prefer a mixed diet, but with consistent foraging activity. Ethol 00: 1-11. DOI: 10.1111/eth.13020.
Sanger G, Rarung LK, Kasege BE, Assa JR, Agustin AT. 2019. Phenolic content and antioxidant activities of five seaweeds from North Sulawesi Indonesia. AACl Bioflux 12 (6): 2041-2050.

Sarojini Y, Sujatha B, Rao PS. 2016. The variation in distribution of total phenols and antioxidant activity in five species of marine macroalgae. Der Pharmacia Lettre 8 (1): 30-37.

Setyono DED. 2006. Food Preferences for juvenile tropical abalon (Hasliotis asinina). Oseanologi dan Limnologi di Indonesia 41 (1): 114

Susanto B, Rusdi I, Ismi S, Rahmawati R. 2010. Rearing of abalone (Haliotis squamata) F-1 generation juvenile through different kinds of $\begin{array}{llll}\text { feed. J Ris Akuakultur 5 (2): 199-209. DOI: } & \end{array}$ 10.15578/jra.5.2.2010.199-209.

Venter L, Loots DT, Vosloo A, Van Rensburg PJ, Lindeque JZ. 2016. Abalone growth and associated aspects: Now from a metabolic perspective. Rev Aqua 10: 451-473. DOI: 10.1111/raq.12181.

Vidal N, González-Bergonzoni I, Naya DE. 2018. The effect of fasting on nutritional status, organs size and isotopic composition in a Neotropical fish species (Jenynsia multidentata). Hydrobiologia 828: 73-82. DOI: 10.1007/s10750-018-3803-9.

Viera MP, Curtois de VG, Gomez-Pinch JL, Bilbao A, FernandezPalacios H, Izquiedo MS. 2011. Comparative performances of juvenile abalone (Haliotis tuberculate coccinea Reeve) fed enriched vZ non-enriched: Effect on growth and body composition. Aquaculture 319: 423-429. DOI: 10.1016/j.aquaculture.2011.07.024.

Yusup DS. 2020. Feeding Behaviour and Macroalgae Based Ration formulation for pre-adult abalone Haliotis squamata. [Disertation]. University of Udayana, Denpasar. [Indonesian].

Yusup DS, Suaskara IB, Indrawan GS, Triwiyanto K. 2014. Potency and exploitation level of abalone (Haliotis squamata) at Cemagi Village, Mengwi Badung. In: Suarsana IN (eds). The Environmental- Base Role of Science and Technology on Human Welfare Improvement. Proceeding of National Seminary Science and Technology 2014. Udayana University, Denpasar, 18-19 September 2014. [Indonesian].

Yusup DS. 2015. Culture cage evaluation for observation on abalone fresh feeding: plastic box and floating net. In: Wirastuti NMAED (eds). Innovation on Humanities, Science and Technology for Sustainable Development. Proceeding of National Seminary Science and Technology 2015. Udayana University, Kuta, 29-30 October 2015 [Indonesian].

Zhanhui Qi, Liu H, Li B, Mao Y, Jiang Z, Zhang J, Fang J. 2010. Suitability of two seaweeds, Gracillaria lemaneiformis and Sargassum pallidum, as feed for the abalone Haliotis discus hannai ino. Aquaculture 300: 189-193. DOI: 10.1016/j.aquaculture.2010.01.019.

Ziheng F, Xiangli T, Shuanglin D. 2017. Effect of starving and re-feeding strategies on the growth performance and physiological characteristics of the juvenile Tongule sole (Cynoglossus semilaevis). J Ocean Univ China (Ocean and Coast Sea Res) 16 (3): 517-524. DOI: $10.1007 / \mathrm{s} 11802-017-3198-7$. 